\title{
10. PEER PRODUCTION AND COLLECTIVE INTELLIGENCE AS THE BASIS FOR THE PUBLIC DIGITAL UNIVERSITY
}

Due to rights restrictions, this chapter (pp. 157-175) is not available as individual file in electronic format. It is originally published as Peters, M. A., \& Jandrić, P. (2018). Peer Production and Collective Intelligence as the Basis for the Public Digital University. Educational Philosophy and Theory, copyright (C) Philosophy of Education Society of Australasia, reprinted by permission of Taylor \& Francis Ltd, http://www.tandfonline.com on behalf of Philosophy of Education Society of Australasia. 